\title{
No Evidence of SARS-CoV-2 Infection in Neotropical Primates Sampled During COVID-19 Pandemic in Minas Gerais and Rio Grande do Sul, Brazil
}

Filipe Vieira Santos de Abreu $\left(\mathbb{D},{ }^{1}\right.$ Mariana Viana Macedo, ${ }^{2}$ Alex Junio Jardim da Silva, ${ }^{1}$ Cirilo Henrique de Oliveira, ${ }^{1}$ Vinícius Oliveira de Ottone, ${ }^{2}$ Marco Antônio Barreto de Almeida $\mathbb{1},{ }^{3}$ Edmilson dos Santos, ${ }^{3}$ Jader Cruz da Cardoso, ${ }^{3}$ Aline Scarpellini Campos, ${ }^{3}$ Claudia Maria Dornelles da Silva, ${ }^{3}$ Amanda Gonzales da Silva, ${ }^{3}$ Miguel Souza de Andrade, ${ }^{4}$ Valéria Magro Octaviano Bernis, ${ }^{1}$ Walter Octaviano Bernis Filho, ${ }^{1}$ Giliane Souza de Trindade, ${ }^{5}$ George Rego Albuquerque, ${ }^{6}$ Anaiá Paixão da Sevá, ${ }^{6}$ Bergmann Morais Ribeiro, ${ }^{4}$ Danilo Simonini Teixeira, ${ }^{6}$ Fabrício Souza Campos, ${ }^{7}$ Ana Cláudia Franco, ${ }^{8}$ Paulo Michel Roehe, ${ }^{8}$ and Danilo Bretas de Oliveira ${ }^{2}$

\footnotetext{
${ }^{1}$ Insect Behavior Laboratory, Instituto Federal do Norte de Minas Gerais, Salinas, MG 39560-000, Brazil

${ }^{2}$ Medical School, Health Science Post-Graduate Program, Universidade Federal dos Vales do Jequitinhonha e Mucuri, Campus JK - Rodovia MGT 367 Km 583, $n^{\circ} 5000$ - Alto da Jacuba, Diamantina, MG 39100-000, Brazil

${ }^{3}$ Centro Estadual de Vigilância em Saúde, Secretaria de Saúde do Rio Grande do Sul, Porto Alegre, RS 90450-190, Brazil

${ }^{4}$ Cell Biology Department, Biology Institute, Universidade de Brasília, Brasília 70910-900, Brazil

${ }^{5}$ Laboratório de Vírus, Departamento de Microbiologia, Instituto de Ciências Biológicas, Universidade Federal de Minas Gerais, Belo Horizonte, MG 31270-901, Brazil

${ }^{6}$ Department of Agricultural and Environmental Sciences, State University of Santa Cruz, Ilhéus, BA 45662-900, Brazil

${ }^{7}$ Laboratory of Bioinformatics and Biotechnology, Universidade Federal de Tocantins, Gurupi, TO 77402-970, Brazil

${ }^{8}$ Laboratório de Virologia, Departamento de Microbiologia, Imunologia e Parasitologia, Universidade Federal do Rio Grande do Sul, Porto Alegre, RS 90050-170, Brazil
}

\begin{abstract}
In 2019, a new coronavirus disease (COVID-19) was detected in China. Severe acute respiratory syndrome coronavirus 2 (SARS-CoV-2) was capable to infect domestic and captive mammals like cats, tigers and minks. Due to genetic similarities, concern about the infection of non-human primates (NHPs) and the establishment of a sylvatic cycle has grown in the Americas. In this study, neotropical primates (NP) were sampled in different areas from Brazil to investigate whether they were infected by SARS-CoV-2. A total of 89 samples from $51 \mathrm{NP}$ of four species were examined. No positive samples were detected via RT-qPCR, regardless of the NHP species, tissue or habitat tested. This work provides the first report on the lack of evidence of the circulation of SARS-CoV-2 in NP. The expansion of wild animals sampling is necessary to understand their role in the epidemiology of SARS-CoV-2 and other potentially zoonotic pathogens in natural environments shared by humans.
\end{abstract}

Keywords: Coronavirus, Callithrix, Alouatta, spillover, spillback, nonhuman-primate

Published online: November 29, 2021

Correspondence to: Danilo Bretas deOliveira,e-mail: danilo.bretas@ufvjm.edu.br
In December 2019, a new disease caused by a virus belonging to the Coronaviridae family was first detected in 
the city of Wuhan, China, and was named coronavirus disease (COVID-19) (Wu et al. 2020). The etiologic agent-Severe Acute Respiratory Syndrome Coronavirus 2 (SARS-CoV-2) - is highly transmissible among humans through droplets of saliva and quickly spread across the planet. In March 2020, the virus reached every continent which led the World Health Organization to declare COVID-19 as a pandemic (World Health Organization).

Initial studies of epidemiology and genetic comparison showed that the new virus has a high similarity to other coronaviruses found in bats and pangolin (96 and 91\% similarity, respectively) (Zhang et al. 2020) and that the "spillover," that is, the "jump" between hosts, might have occurred in the vicinity of the popular market in Wuhan, where these animals are traditionally traded for human consumption (Wu et al. 2020). Thenceforth, it has been questioned whether SARS-CoV-2 would be able to perform a "spillback"-transmission from humans to wild animals-which could generate wild cycles of the virus, making it even more difficult to face.

In this regard, concern about the infection of nonhuman primates (NHPs) has grown since the biological, genetic and biochemical similarities between humans and these species could facilitate the transmission of SARSCoV-2 to NHPs. Comparative studies have indicated that the cellular receptor angiotensin-converting enzyme 2 (ACE2), used by this virus for adsorption to cells, is similar between humans and NHPs, especially in Old World species; as such, these have been used as experimental models for the study of SARS-CoV-2 (Melin et al. 2020). In the Americas, there is a great concern about the risks of SARSCoV-2 spillback from humans to wildlife, including neotropical NHPs. This could have at least two impacts: a) establishment of a sylvatic cycle with serious implications on control or eradication efforts, and: b) unforeseeable impact on biodiversity, especially if endangered NHP species become involved. The historical comparison with the yellow fever virus (YFV), whose sylvatic cycle was first recognized almost a century ago after a spillback from humans to NHPs, exemplifies the potential damage that may be associated with such impacts (Possas et al. 2018).

To our knowledge, the only neotropical primate species experimentally infected with SARS-CoV-2 was the marmoset Callithrix jacchus. Infected individuals had pyrexia and viral RNA loads detectable for several days postinfection in oral, nasal and anal swabs, as well as in blood and stool samples (Lu et al. 2020). However, little is known about the possibility of viral infection in natural conditions and in other neotropical primates' families or species. Worryingly, in many Brazilian cities where cases of COVID-19 are currently reaching unprecedented levels, Callithrix spp. are adapted to synanthropic environments, often kept as pets and feeding on human foods. Such coexistence might represent a significant potential source of infection (Longa et al. 2011). In addition, the rapid dissemination of SARS-CoV-2 currently verified throughout Brazil can lead to the exposure of other NHPs, including wild species.

The present study was carried out in search of virological evidence of SARS-CoV-2 infections in NHPs from urban, sylvatic and rural areas of two Brazilian states, Minas Gerais (MG) and Rio Grande do Sul (RS). The current study is part of a wider NHP sampling effort whose main goal is to contribute to the national program for epidemiological surveillance of yellow fever.

Neotropical Primates' samplings were performed before (November 2019) and during (July 2020-February 2021) the COVID-19 pandemic in two Brazilian states. Initially in MG (Brazil's Southeast region), where the savannah-like biome predominates, captures occurred in four municipalities (Fig. 1a). Later on in RS (Brazil's South region), which is covered by Atlantic Forest and Pampa biomes, captures were conducted in seven municipalities (Fig. 1b) (Andrade et al. 2021). Human COVID-19 cases per 100.000 inhabitants up to the sampling efforts are highlighted by the colors of the municipalities on the map (SES-MG 2020; SES-RS 2021).

Live marmosets were captured with Tomahawk traps, according to the protocol previously described (Abreu et al. 2019a). Dead or sick marmosets and howler monkeys were also examined. In MG, they were found based on an information network made up of health professionals, farmers and other people in contact with natural environments, as described elsewhere (Abreu et al. 2019b) while in RS, staff from the State Health Department found and reported the epizootics. Serum and/or oral swab (of live animals), as well as whole blood and/or viscera (lung, liver or kidney of dead animals), were collected, preserved in RNAlater (Thermo Fisher ${ }^{\mathrm{TM}}$ ) and stored in liquid nitrogen at $-196^{\circ} \mathrm{C}$. Our methods and protocols followed the collection routine of yellow fever surveillance program and were previously approved by the Institutional Ethics Committee for Animal Experimentation (Protocol CEUA/ IFNMG $n^{\circ} 14 / 2019$ ) and by the Brazilian Ministry of the Environment (SISBIO no. 71,714-2). 


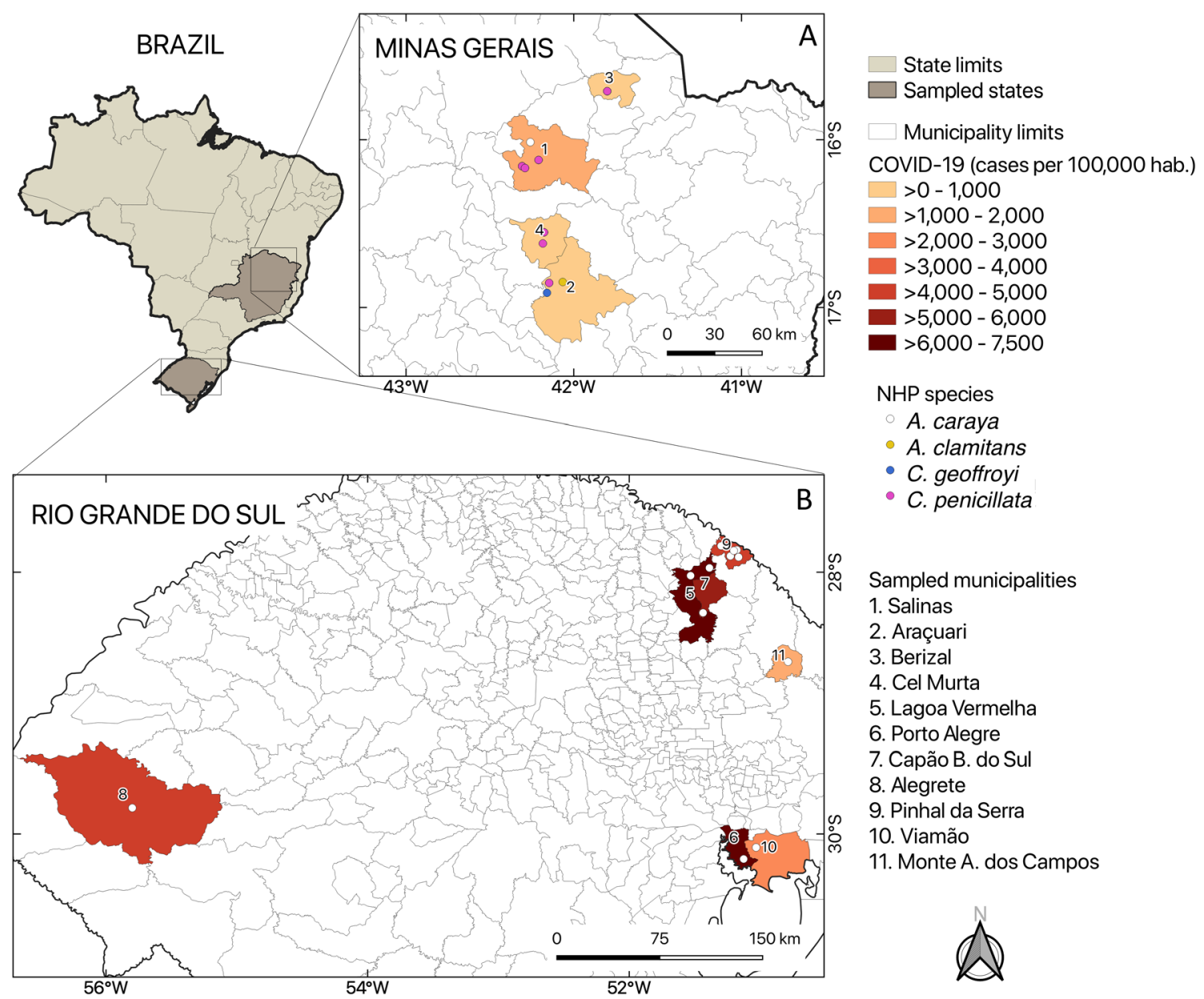

Figure 1. Municipalities where sampling of NHPs was performed. a Minas Gerais state; b Rio Grande do Sul state. The number of COVID-19 human cases in each municipality was counted until the sample collection date. Data were obtained from state health departments (SES-MG 2020; SES-RS 2021). The figure was done using QGIS software, version 3.10.

RNA extractions were performed using QIAamp Viral RNA Mini Kit $\left(\right.$ QIAGEN $^{\circledR}$ (for serum) and TRIzol ${ }^{\mathrm{TM}}$ Reagent (Thermo Fisher ${ }^{\mathrm{TM}}$ ) (for viscera) following manufacturer's instructions. Detection of the SARS-CoV-2 viral RNA in samples from MG was performed using a real-time RT-PCR kit (CDC 2019-nCoV Real-Time RT-PCR Diagnostic Panel, which targets the N1 (2019-nCoV_N1 Combined Primer/Probe Mix) and N2 (2019-nCoV_N2 Combined Primer/Probe Mix) genes of the SARS-CoV-2 (CDC Division of Viral Diseases 2020). In RS, viral RNA detection was performed using the Allplex ${ }^{\mathrm{TM}}$ 2019-nCoV $\left(\right.$ Seegene ${ }^{\circledR}$ ), which targets genomic regions within the $E$, $R d R P$ and $N$ genes. Commercial positive control (2019nCoV_N_Positive Control, catalog number: 10006622) containing the complete nucleocapsid gene sequence (IDT Technologies) as well as samples from known SARS-CoV- 2-positive human patients were used as positive controls during the molecular assays.

In total, 51 NHPs belonging to two different families (Callitrichidae and Atelidae) and four species (Callithrix penicillata, C. jacchus, Alouatta caraya and A. guariba clamitans) were examined (Table 1). Seven NHPs were captured before the reported virus introduction (AugustNovember/2019) and 44 after the introduction (July 2020February 2021). Different tissues were analyzed, totalizing 89 samples: 30 serum, 20 oral swabs, 19 liver, 14 kidney, 3 lung and 3 whole blood (Table 1). No SARS-CoV-2 positive samples were detected, regardless of NHP species, tissue, habitat, municipalities or state/biome tested (Table 1).

This was the first study evaluating the possibility of natural infection of free-living neotropical NHPs with SARS-CoV-2. We found no evidence of SARS-CoV-2 infection in NHPs from urban, rural or sylvatic habitats 
Table 1. Description of Samples Tested by Species, Tissue, Habitat, Date, Municipality (City) and State.

\begin{tabular}{|c|c|c|c|c|c|c|c|c|c|c|c|}
\hline ID & Species & Serum & Oral swab & Whole blood & Liver & Lung & Kidney & Habitat & Collection date & City & State \\
\hline${\mathrm{MG} 02^{*}}^{*}$ & A. caraya & - & - & Neg & $\mathrm{Neg}$ & Neg & - & Sylvatic & $20 / 08 / 2019$ & 1 & MG \\
\hline MG03 & C. penicillata & $\mathrm{Neg}$ & - & - & - & - & - & Rural & $22 / 11 / 2019$ & & \\
\hline MG04 & C. penicillata & $\mathrm{Neg}$ & - & - & - & - & - & Rural & $22 / 11 / 2019$ & & \\
\hline MG05 & C. penicillata & $\mathrm{Neg}$ & - & - & - & - & - & Rural & $22 / 11 / 2019$ & & \\
\hline MG06 & C. penicillata & Neg & - & - & - & - & - & Rural & $22 / 11 / 2019$ & & \\
\hline MG07 & C. penicillata & $\mathrm{Neg}$ & - & - & - & - & - & Rural & $22 / 11 / 2019$ & & \\
\hline MG08 & C. penicillata & $\mathrm{Neg}$ & - & - & - & - & - & Rural & $22 / 11 / 2019$ & & \\
\hline MG10 & C. penicillata & $\mathrm{Neg}$ & - & - & - & - & - & Sylvatic & $04 / 07 / 2020$ & & \\
\hline MG11 & C. penicillata & $\mathrm{Neg}$ & - & - & - & - & _ & Sylvatic & $04 / 07 / 2020$ & & \\
\hline MG12 & C. penicillata & Neg & - & - & - & - & _ & Sylvatic & $04 / 07 / 2020$ & & \\
\hline MG13 & C. penicillata & Neg & - & _ & - & - & _ & Sylvatic & $04 / 07 / 2020$ & & \\
\hline MG21* & C. penicillata & _ & Neg & _ & $\mathrm{Neg}$ & - & _ & Urban & $30 / 08 / 2020$ & & \\
\hline $\mathrm{MG}_{2} 2^{*}$ & C. penicillata & - & Neg & Neg & $\mathrm{Neg}$ & - & - & Urban & $30 / 08 / 2020$ & & \\
\hline MG23* & C. penicillata & - & Neg & Neg & Neg & - & - & Urban & $30 / 08 / 2020$ & & \\
\hline MG24 & C. penicillata & Neg & Neg & - & - & - & - & Urban & $12 / 09 / 2020$ & & \\
\hline MG25 & C. penicillata & Neg & Neg & - & - & - & - & Urban & $19 / 09 / 2020$ & & \\
\hline MG26 & C. penicillata & $\mathrm{Neg}$ & Neg & - & - & - & - & Urban & $21 / 09 / 2020$ & & \\
\hline MG14 & C. penicillata & $\mathrm{Neg}$ & - & - & - & - & - & Rural & $30 / 07 / 2020$ & 2 & \\
\hline MG15 & C. penicillata & $\mathrm{Neg}$ & - & - & - & - & - & Rural & $30 / 07 / 2020$ & & \\
\hline MG17 & C. penicillata & $\mathrm{Neg}$ & - & - & - & - & - & Rural & $30 / 07 / 2020$ & & \\
\hline MG18 & C. penicillata & Neg & - & - & - & - & _ & Rural & $30 / 07 / 2020$ & & \\
\hline MG19 & C. penicillata & Neg & _ & - & - & _ & _ & Rural & $30 / 07 / 2020$ & & \\
\hline MG20 & C. penicillata & Neg & - & _ & _ & - & _ & Rural & $30 / 07 / 2020$ & & \\
\hline MG28 & C. penicillata & _ & Neg & _ & _ & - & _ & Rural & $18 / 10 / 2020$ & 3 & \\
\hline MG29 & C. penicillata & $\mathrm{Neg}$ & Neg & _- & _ & - & _- & Rural & $18 / 10 / 2020$ & & \\
\hline MG30 & C. penicillata & Neg & Neg & - & - & - & - & Rural & $18 / 10 / 2020$ & & \\
\hline MG31 & C. penicillata & $\mathrm{Neg}$ & Neg & - & - & - & - & Rural & $18 / 10 / 2020$ & & \\
\hline MG32 & C. geoffroyi & $\mathrm{Neg}$ & $\mathrm{Neg}$ & - & - & - & - & Rural & $18 / 10 / 2020$ & & \\
\hline MG33 & C. penicillata & $\mathrm{Neg}$ & $\mathrm{Neg}$ & - & - & - & - & Rural & $19 / 10 / 2020$ & 4 & \\
\hline MG34 & C. penicillata & Neg & Neg & - & - & - & - & Rural & $19 / 10 / 2020$ & & \\
\hline MG35 & C. penicillata & $\mathrm{Neg}$ & Neg & - & - & - & _ & Rural & $20 / 10 / 2020$ & & \\
\hline MG36 & C. penicillata & Neg & Neg & _ & - & - & _ & Rural & $20 / 10 / 2020$ & & \\
\hline MG37* & C. penicillata & - & $\mathrm{Neg}$ & - & - & Neg & - & Rural & $20 / 10 / 2020$ & & \\
\hline MG38 & C. penicillata & Neg & Neg & - & - & - & - & Rural & $20 / 10 / 2020$ & & \\
\hline MG39 & C. penicillata & Neg & Neg & - & - & - & - & Urban & $21 / 10 / 2020$ & & \\
\hline MG40 & C. penicillata & Neg & Neg & - & - & - & - & Urban & $21 / 10 / 2020$ & & \\
\hline MG41* & A. clamitans & - & Neg & - & Neg & Neg & - & Urban & $22 / 10 / 2020$ & & \\
\hline $\mathrm{RS}_{0}{ }^{*}$ & A. clamitans & - & - & - & $\mathrm{Neg}$ & - & Neg & Sylvatic & $25 / 01 / 2021$ & 5 & RS \\
\hline $\mathrm{RSO2}^{*}$ & A. clamitans & - & - & - & $\mathrm{Neg}$ & - & Neg & Sylvatic & $25 / 01 / 2021$ & & \\
\hline $\mathrm{RS}^{*}{ }^{*}$ & A. clamitans & - & - & - & $\mathrm{Neg}$ & - & $\mathrm{Neg}$ & Sylvatic & $25 / 01 / 2021$ & & \\
\hline $\mathrm{RS} 4^{*}$ & A. clamitans & - & - & - & $\mathrm{Neg}$ & - & $\mathrm{Neg}$ & Sylvatic & $5 / 2 / 2021$ & & \\
\hline $\mathrm{RS} 5^{*}$ & A. clamitans & - & - & _ & Neg & - & Neg & Sylvatic & $8 / 2 / 2021$ & & \\
\hline $\mathrm{RS}^{*} 6^{*}$ & A. clamitans & - & - & _ & Neg & _ & Neg & Sylvatic & $9 / 2 / 2021$ & & \\
\hline $\mathrm{RS} 7^{*}$ & A. clamitans & _ & - & _ & $\mathrm{Neg}$ & - & Neg & Sylvatic & $11 / 2 / 2021$ & & \\
\hline $\mathrm{RS} 8^{*}$ & A. caraya & - & - & - & $\mathrm{Neg}$ & - & Neg & Urban & $11 / 2 / 2021$ & 6 & \\
\hline $\mathrm{RS}^{*}{ }^{*}$ & A. clamitans & - & - & - & Neg & - & Neg & Rural & $16 / 2 / 2021$ & 7 & \\
\hline RS10* & A. clamitans & _ & - & _- & $\mathrm{Neg}$ & _- & Neg & Sylvatic & $10 / 2 / 2021$ & 8 & \\
\hline
\end{tabular}


Table 1. Continued

\begin{tabular}{|c|c|c|c|c|c|c|c|c|c|c|c|}
\hline ID & Species & Serum & Oral swab & Whole blood & Liver & Lung & Kidney & Habitat & Collection date & City & State \\
\hline $\mathrm{RS} 11^{*}$ & A. clamitans & - & _ & _ & Neg & _ & Neg & Urban & $15 / 1 / 2021$ & 9 & \\
\hline $\mathrm{RS}_{12}{ }^{*}$ & A. clamitans & - & - & - & Neg & - & $\mathrm{Neg}$ & Rural & $2 / 2 / 2021$ & 10 & \\
\hline $\mathrm{RS}_{13}{ }^{*}$ & A. clamitans & - & - & - & Neg & - & Neg & Sylvatic & $5 / 2 / 2021$ & & \\
\hline $\mathrm{RS} 14^{*}$ & A. clamitans & _- & - & _ & Neg & - & $\mathrm{Neg}$ & Rural & $8 / 2 / 2021$ & 11 & \\
\hline
\end{tabular}

Legend: Neg: negative sample;- - not tested;

^Animals found dead; 1: Salinas; 2: Berizal; 3: Araçuaí; 4: Coronel Murta; 5: Pinhal da Serra; 6: Alegrete; 7: Porto Alegre; 8: Capão Bonito do Sul; 9: Viamão; 10: Lagoa Vermelha; 11: Monte Alegre dos Campos. MG: Minas Gerais; RS: Rio Grande do Sul.

regardless of the tissues or species surveyed. Despite that, in view of the widespread dissemination of SARS-CoV-2, it is important to maintain and expand the surveillance of wildlife, aiming at the early detection of spillovers or spillbacks among human beings and other animals.

Since its first detection, reports of natural SARS-CoV-2 infection of several animals have accumulated, including domestic animals like cats (Sailleau et al. 2020; Carlos et al. 2021), dogs (Sit et al. 2020) and wild captive animals like tigers (McAloose et al. 2020) and minks (Hammer et al. 2021). Minks have also been described as a source of infection for humans (Hammer et al. 2021). In addition, experimental infection studies have reported susceptibility of several animals such as ferrets, bats, hamsters (Shi et al. 2020; Imai et al. 2020) and mainly Old World NHPs (Zheng et al. 2020; Lu et al. 2020). As a result, concern about the possibility of SARS-CoV-2 spillback for Neotropical Primates-as happened with YFV in the last century and probably with ZIKA in the last decade-has grown (Terzian et al. 2018; Yunes Guimarães et al. 2020). However, the only report of experimental infection in a neotropical NHP published to date examined the dynamics of SARS-CoV-2 infection in Callithrix jacchus, the common marmoset. Viral genomes were detected in oral, nasal and anal swabs as well as in serum and feces, despite the lower susceptibility of that species when compared to Old World Primates. (Lu et al. 2020). In the present study, all tissues sampled from the 44 free-living primates collected after the introduction of the virus in Brazil presented no evidence of SAR-CoV-2 infection, including samples from NHP living in rural and urban environments, in close contact with humans.

The cellular receptor ACE2 used by the virus for adsorption to cells is a major determinant in the susceptibility of animals to SARS-CoV-2 infection. The ACE2 receptor of cells from Old World NHPs have up to $99 \%$ identity with human ACE2 protein, which might contribute significantly to the high susceptibility that such species display to infection with this virus (Shi et al. 2020; Melin et al. 2020). Neotropical NHPs, such as those sampled in the present study, have ACE2 receptors that share about $92 \%$ identity to human ACE2, with four differences across the twelve binding sites regarded as essential for the ACE2 protein to allow binding of SARS-CoV-2 (Melin et al. 2020; Joyraj Bhattacharjee et al. 2021). This may be related to species' differences in susceptibility and, possibly, with our negative results, even in NHPs living in urban areas with high SARS-CoV-2 human incidence. Even so, it is important to investigate whether the new variants of SARS-CoV-2 could increase their infectivity in wild animals.

Brazil is the country with the greatest biodiversity on the planet and concentrates the largest number of NHP species, many of these are endangered due to anthropogenic effects such as deforestation which, in addition to drastically reducing habitats, increases the risks of zoonotic transmissions (Paglia et al. 2012; Guthid et al. 2020). The explosive spread of SARS-CoV-2 in the country, particularly in areas where contact between humans and native fauna is frequent, provides conditions for spillovers and spillback which increases the need for surveillance for early identification and contingency of the potentially harmful effects (Gryseels et al. 2020). In this sense and despite the small sampling, our study contributes to shedding light on the subject by providing the first results about the absence of circulation of SARS-CoV-2 in Neotropical Primates. It is urgent to expand the sampling of NHP living in different environments, to include other primate species and even other mammals to carry out active surveillance of wild animals and understand the epidemiology of SARS-CoV-2 in natural environments. 


\section{ACKNOWLEDGEMENTS}

The authors thanks to all institutions and technicians that contributed and supported the field work. We are especially grateful to Centro de Estudo Multidisciplinar em Conservação Animal IFNMG - Salinas (CEMCA), Aline Tátila Ferreira, Sandy Micaele Aquino Teixeira, Maria Eduarda Gonçalves dos Santos and Pedro Augusto Almeida Souza, for their valuable contribution during the field work. We are also grateful to members of Secretaria de Saúde and Centro de Controle de Zoonoses de Salinas, Berizal, Rubelita, and Coronel Murta; and Rio Grande do Sul State Health Department: Members of Yellow Fever Surveillance State Reference Team. We also thank Conselho Nacional de Desenvolvimento Científico e Tecnológico (CNPq) for scholarship awarded.

\section{FUNDING}

Conselho Nacional de Desenvolvimento Científico e Tecnológico (CNPq) Grant No. 443215/2019-7 and 401933/ 2020-2; IFNMG Grant No. 21/2020. P.M.R. is a CNPq research fellow.

\section{Declarations}

CONFLICT OF INTEREST The authors declare no conflict of interests or competing interests.

ETHICAL APPROVAL All applicable institutional and/ or national guidelines for the care and use of animals were followed. Methods and protocols were previously approved by the Institutional Ethics Committee for Animal Experimentation (Protocol CEUA/IFNMG $n^{\circ} 14 / 2019$ ) and by Brazilian Ministry of the Environment (SISBIO n ${ }^{\circ} 71714$ 2). This article does not contain any studies with human participants.

\section{REFERENCES}

Abreu FVS, dos Santos E, Gomes MQ, Vargas WP, Oliveira Passos PH, Nunes e Silva C, Araújo PC, Pires JR, Romano APM, Teixeira DS, Lourenço-de-Oliveira R (2019) Capture of Alouatta guariba clamitans for the surveillance of sylvatic yellow fever and zoonotic malaria: Which is the best strategy in the tropical Atlantic Forest? Am J Primatol 81:e23000

Carlos RSA, Mariano APM, Maciel BM, Gadelha SR, Melo Silva M, Belitardo EMMA, Rocha DJPG, Almeida JPP, Pacheco LGC,
Aguiar ERGR, Fehlberg HF, Albuquerque GR (2021) First genome sequencing of SARS-CoV-2 recovered from an infected cat and its owner in Latin America. Transbound Emerg Dis tbed.13984 . https://doi.org/10.1111/tbed.13984

CDC Division of Viral Diseases (2020) CDC 2019-Novel Coronavirus (2019-nCoV) Real-Time RT-PCR Diagnostic Panel 2019nCoVEUA-01 CDC-006-00019, Revision: 06. https://www.fda.g ov/media/134922/download. Accessed 5 Dec 2020

de Abreu FVS, dos Santos E, Mello ARL, Gomes LR, de Alvarenga DAM, Gomes MQ, Vargas WP, Bianco-Júnior C, de Pina-Costa A, Teixeira DS, Romano APM, de Manso PPA, Pelajo-Machado M, Brasil P, Daniel-Ribeiro CT, de Brito CFA, de Ferreira-daCruz MF, Lourenço-de-Oliveira R (2019) Howler monkeys are the reservoir of malarial parasites causing zoonotic infections in the Atlantic forest of Rio de Janeiro. PLoS Negl Trop Dis 13:e007906

de Andrade MS, Campos FS, Campos AAS, Abreu FVS, Melo FL, da Sevá AP, da Cardoso JC, Dos SE, Born LC, da Silva CMD, Müller NFD, de Oliveira CH, da Silva AJJ, Simonini-Teixeira D, Bernal-Valle S, Mares-Guia MAMM, Albuquerque GR, Romano APM, Franco AC, Ribeiro BM, Roehe PM, de Almeida MAB (2021) Real-Time Genomic Surveillance during the $2021 \mathrm{Re}-$ Emergence of the Yellow Fever Virus in Rio Grande do Sul State and Brazil. Viruses 13:1976

Gryseels S, De Bruyn L, Gyselings R, Calvignac-Spencer S, Leendertz FH, Leirs H (2020) Risk of human-to-wildlife transmission of SARS-CoV-2. Mamm Rev . https://doi.org/10.1111/ mam. 12225

Guthid S, Hanley KA, Althouse BM, Boots M (2020) Ecological processes underlying the emergence of novel enzootic cycles: Arboviruses in the neotropics as a case study. PLoS Negl. Trop. Dis. 14:1-22

Hammer AS, Quaade ML, Rasmussen TB, Fonager J, Rasmussen M, Mundbjerg K, Lohse L, Strandbygaard B, Jørgensen CS, Alfaro-Núñez A, Rosenstierne MW, Boklund A, Halasa T, Fomsgaard A, Belsham GJ, Bøtner A (2021) SARS-CoV-2 transmission between mink (neovison vison) and Humans, Denmark. Emerg Infect Dis 27:547-551. https://doi.org/10.3201/ eid2702.203794

Imai M, Iwatsuki-Horimoto K, Hatta M, Loeber S, Halfmann PJ, Nakajima N, Watanabe T, Ujie M, Takahashi K, Ito M, Yamada S, Fan S, Chiba S, Kuroda M, Guan L, Takada K, Armbrust T, Balogh A, Furusawa Y, Okuda M, Ueki H, Yasuhara A, SakaiTagawa Y, Lopes TJS, Kiso M, Yamayoshi S, Kinoshita N, Ohmagari N, Hattori SI, Takeda M, Mitsuya H, Krammer F, Suzuki T, Kawaoka Y (2020) Syrian hamsters as a small animal model for SARS-CoV-2 infection and countermeasure development. Proc Natl Acad Sci U S A 117:16587-16595. https:// doi.org/10.1073/pnas.2009799117

Joyraj Bhattacharjee M, Lin J-J, Chang C-Y, Chiou Y-T, Li T-N, Tai C-W, Shiu T-F, Chen C-A, Chou C-Y, Chakraborty P, Yuan Tseng Y, Hui-Ching Wang L, Li W-H (2021) Identifying primate ACE2 variants that confer resistance to SARS-CoV-2. Mol Biol Evol . https://doi.org/10.1093/molbev/msab060

Longa CS, Bruno SF, Pires AR, Romijn PC, Kimura LS, Costa CHC (2011) Human herpesvirus 1 in wild marmosets, Brazil, 2008. Emerg. Infect. Dis. 17:1308-1310

Lu S, Zhao Y, Yu W, Yang Y, Gao J, Wang J, Kuang D, Yang M, Yang J, Ma C, Xu J, Qian X, Li H, Zhao S, Li J, Wang H, Long H, Zhou J, Luo F, Ding K, Wu D, Zhang Y, Dong Y, Liu Y, Zheng Y, Lin X, Jiao L, Zheng H, Dai Q, Sun Q, Hu Y, Ke C, Liu $\mathrm{H}$, Peng X (2020) Comparison of nonhuman primates identi- 
fied the suitable model for COVID-19. Signal Transduct Target Ther 5:1-9. https://doi.org/10.1038/s41392-020-00269-6

McAloose D, Laverack M, Wang L, Killian ML, Caserta LC, Yuan F, Mitchell PK, Queen K, Mauldin MR, Cronk BD, Bartlett SL, Sykes JM, Zec S, Stokol T, Ingerman K, Delaney MA, Fredrickson R, Ivančić $M$, Jenkins-Moore $M$, Mozingo $K$, Franzen K, Bergeson NH, Goodman L, Wang H, Fang Y, Olmstead C, McCann C, Thomas P, Goodrich E, Elvinger F, Smith DC, Tong S, Slavinski S, Calle PP, Terio K, Torchetti MK, Diel DG (2020) From people to panthera: Natural sars-cov-2 infection in tigers and lions at the bronx zoo. Mbio 11:1-13. https://doi.org/10.1128/mBio.02220-20

Melin AD, Janiak MC, Marrone F, Arora PS, Higham JP (2020) Comparative ACE2 variation and primate COVID-19 risk. Commun Biol 3:1-9. https://doi.org/10.1038/s42003-020-01370$\mathrm{w}$

Paglia AP, Rylands AB, Herrmann G, Aguiar LMS, Chiarello AG, Leite YLR, Costa LP, Siciliano S (2012) Lista anotada dos mamiferos do Brasil, segunda edicao, 2nd edn. Conservation International, Arlington

Possas C, Lourenço-de-oliveira R, Tauil PL, Pinheiro FDP, Pissinatti A, Venâncio R, Freire M, Martins RM, Homma A (2018) Yellow fever outbreak in Brazil : the puzzle of rapid viral spread and challenges for immunisation. Mem Inst Oswaldo Cruz 113:1-12. https://doi.org/10.1590/0074-02760180278

Sailleau C, Dumarest M, Vanhomwegen J, Delaplace M, Caro V, Kwasiborski A, Hourdel V, Chevaillier P, Barbarino A, Comtet L, Pourquier P, Klonjkowski B, Manuguerra J, Zientara S, Le Poder S (2020) First detection and genome sequencing of SARSCoV-2 in an infected cat in France. Transbound Emerg Dis 67:2324-2328. https://doi.org/10.1111/tbed.13659

SES-MG (2020) COVID-19 Coronavírus Boletim Minas Gerais. Belo Horizonte

SES-RS (2021) SES/RS - Coronavirus. https://ti.saude.rs.gov.br/c ovid19/. Accessed 22 Mar 2021

Shi J, Wen Z, Zhong G, Yang H, Wang C, Huang B, Liu R, He X, Shuai L, Sun Z, Zhao Y, Liu P, Liang L, Cui P, Wang J, Zhang X, Guan Y, Tan W, Wu G, Chen H, Bu Z (2020) Susceptibility of ferrets, cats, dogs, and other domesticated animals to SARScoronavirus 2. Science 368:1016. https://doi.org/10.1126/science.abb7015
Sit THC, Brackman CJ, Ip SM, Tam KWS, Law PYT, To EMW, Yu VYT, Sims LD, Tsang DNC, Chu DKW, Perera RAPM, Poon LLM, Peiris M (2020) Infection of dogs with SARS-CoV-2. Nature 586:776-778. https://doi.org/10.1038/s41586-020-2334-5

Terzian ACB, Zini N, Sacchetto L, Rocha RF, Parra MCP, Del Sarto JL, Dias ACF, Coutinho F, Rayra J, da Silva RA, Costa VV, Fernandes NCCDA, Réssio R, Díaz-Delgado J, Guerra J, Cunha MS, Catão-Dias JL, Bittar C, Reis AFN, dos Santos INP, Ferreira ACM, Cruz LEAA, Rahal P, Ullmann L, Malossi C, de Araújo Jr JP, Widen S, de Rezende IM, Mello É, Pacca CC, Kroon EG, Trindade G, Drumond B, Chiaravalloti-Neto F, Vasilakis N, Teixeira MM, Nogueira ML (2018) Evidence of natural Zika virus infection in neotropical non-human primates in Brazil. Sci Rep 8:16034. https://doi.org/10.1038/s41598-018-34423-6

World Health Organization WHO Director-General's opening remarks at the media briefing on COVID-19 - 11 March 2020. h ttps://www.who.int/director-general/speeches/detail/who-direct or-general-s-opening-remarks-at-the-media-briefing-on-covid19-11-march-2020. Accessed 23 Mar 2021

Wu F, Zhao S, Yu B, Chen YM, Wang W, Song ZG, Hu Y, Tao ZW, Tian JH, Pei YY, Yuan ML, Zhang YL, Dai FH, Liu Y, Wang QM, Zheng JJ, Xu L, Holmes EC, Zhang YZ (2020) A new coronavirus associated with human respiratory disease in China. Nature 579:265-269. https://doi.org/10.1038/s41586-020-2008-3

Yunes Guimarães V, Augusto Justo A, Luís Martins L, Catão-Dias JL, Sacristán C (2020) Emerging coronaviruses in Neotropical primates: A new threat? Rev Ciência Veterinária e Saúde Pública 7:001-012. https://doi.org/10.4025/revcivet.v7i1.55490

Zhang T, Wu Q, Zhang Z (2020) Probable Pangolin Origin of SARS-CoV-2 Associated with the COVID-19 Outbreak. Curr Biol 30:1346-1351.e2. https://doi.org/10.1016/j.cub.2020.03.022

Zheng H, Li H, Guo L, Liang Y, Li J, Wang X, Hu Y, Wang L, Liao Y, Yang F, Li Y, Fan S, Li D, Cui P, Wang Q, Shi H, Chen Y, Yang Z, Yang J, Shen D, Cun W, Zhou X, Dong X, Wang Y, Chen Y, Dai Q, Jin W, He Z, Li Q, Liu L (2020) Virulence and pathogenesis of SARS-CoV-2 infection in rhesus macaques: A nonhuman primate model of COVID-19 progression. PLoS Pathog 16:e1008949. https://doi.org/10.1371/JOURNAL.PPAT.1008949 